\title{
Przewalski Horses in the Wild
}

\author{
By Ivor Montagu
}

The report by Dr Zoltan Kaszab of a sighting of Przewalski wild horses in Mongolia, published in ORYX, December 1966, has brought criticism of the identification. However, an expedition in the summer of 1967 sighted a mare with a yearling foal and found tracks of others. In this article $\mathrm{Mr}$ Ivor Montagu discusses the criticism of the 1966 sighting and Dr Kaszab's reply, and lists other sightings accepted by the Mongolian authorities.

$\mathbf{T}$ HE report of a new sighting of Przewalski horses in the wild in the summer of 1966 by Dr Zoltan Kaszab, Director of the Zoological Department of the Budapest Natural History Museum, has had two consequences. One was an official expedition in the spring of 1967 to the area in which Mongolian scientists believe the animal to survive - the northern slopes of Takhiin Shar nuruu, in the desolate southern part of the Altai range in South Gobi and Gobi-Altai aimaks. This expedition obtained a good sight of a mare and foal and other evidence. The second was a controversy in the pages of the Zeitung für Säugetierkunde between Dr J. Volf of Prague and Dr Kaszab on the exact significance of Dr Kaszab's photograph which was reproduced (in black and white) in ORYX.

The 1967 expedition, which was led by Dr Ozoryn Shagdarsuren, Director of the Biological Institute of the Mongolian Academy of Sciences, was mounted on the initiative of Professor Dr Anudarin Dashdorj, of the Zoological Faculty of Ulan-Bator University; he and Dr Dondogin Tsevegmid (now again Rector of the University), had been the last trained zoologists to see E. przewalskii in the wild, also in this area, in 1955 (4). Professor Dashdorj has sent me (5) (6) a note of its results: 'On May 27th, 1967 , the expedition encountered a mare and yearling foal in the neighbourhood of Takhiin us. * The mare was sandy-bay in colour with a short, erect mane and a darker tail. The yearling colt had not yet entirely got rid of its last year's wool, so that the forepart of its body was reddish-brown and the hindpart brownish-bay. Apart from this encounter with the animals, sightings of tracks occurred in four other places.'

\section{Sightings by Herdsmen}

From current and earlier correspondence with Professor Dashdorj it appears that sightings of $E$. przewalskii in the wild by local herdsmen in this general area have been by no means uncommon throughout the years.

He lists three such accepted sightings in 1966:

June 15th: eleven horses on the northern slopes of Gobi-Servei mountain, by herdsman Tuvden of Tonkhii somon, Gobi-Altai aimak; August: twenty horses and two yearling foals in the region of Khonin us, by 'local

${ }^{*}$ Tr. Wild Horse water - an oasis or damp patch about 60-75 miles from the Chinese frontier on the northern slope of the Takhiin Shar nuruu (Yellow Wild Horse spine). 
inhabitants'; 'Autumn': seven horses on the northern slopes of Takhiin Shar nuruu in the region of Tsakhir massif, by herdsman Khichgei of Altai somon, Khobd aimak. These are in addition to Dr Kaszab's sighting on June 29th at Dukhonin (Tukhumin?) khundi* - about 110-125 miles to the east of the other sighting - of a stallion and seven mares.

In his critique of Dr Kaszab's photograph, Jiři Volf says that an enlargement $\times 50$ fails clearly to establish the subjects as $E$. przewalskii and not $E$. hemionus (the kulan, or wild ass). He maintains that the hidecolour (the original is a $35 \mathrm{~mm}$ snapshot in colour) is too light to be that of any other local wild equid but the kulan.

\section{The Photograph}

Readers of ORYX will remember the photograph which, as reproduced, certainly provided no evidence of species. But this point is made by $\mathrm{Dr}$ Kaszab himself who recalls that he never put it forward as a purported proof, but merely as the best illustration he had of the incident, showing the biotope and the flight of the animals he described. He agrees that the photograph (which he too has enlarged, without any result, owing to the size of the grain) is of no use at all for identification, which depends on his own observation through field-glasses for nearly 20 minutes. The light colour he attributes to underexposure with the animals in sunlight against a dark background. (I have examined the original colour transparency and find this explanation quite possible.)

Professor Dashdorj's comment (6) is that the sighting occurred in a locality from which the animal had not hitherto been reported, that the tails are not distinguishable in the photograph, but that the Mongolians have no reason whatever to doubt Dr Kaszab's own identification by observation which they accept on the basis of his integrity and conscientiousness as a zoologist.

It is not only Dr Volf, the present editor of Equus, the journal devoted to the study and preservation of the Przewalski horses in captivity, but also Dr Zdenek Veselovsky, its former editor and the director of the Prague zoo, who question the continued occurrence of the horse in the wild. A Czechoslovak expedition to the area in the 'fifties failed to find any wild horses. In a personal communication (7) he recalls that no wild horse has been captured since the 'forties, and declares that he was shown as captured horses six animals that were certainly kulans E. hemionus. From this he argues that Mongolian herdsmen lack knowledge of the difference between the takh (the horse) and the kulan - hinting that Dr A. G. Bannikov is also of this opinion. He says that few Mongolian zoologists have competence in mammalogy, and while exempting and paying tribute to Dr Tsevegmid, adds that the latter obtained no direct evidence of the horse during his 1955 expedition and only received evidence of it by hearsay. The opinions of Dr Volf and Dr Veselovsky deserve, of course, every respect, but on this last point, at any rate, the latter is quite mistaken. Dr Tsevegmid has since personally confirmed to me his joint sighting with Professor Dashdorj in 1955 in every particular (4).

*Khundi, tr. Damp hollow, a dried river bed. 
It is also difficult for those who know Mongolian herdsmen, and their familiarity with horses which they ride from the age of four and five years, to suppose that they cannot distinguish between horses and asses when they please (8). That they are not above pulling the legs of foreign visitors is another matter entirely. It would also seem not unlikely that Mongolian scientists, acquainted with the herdsmen and their ways and able to crossexamine them in their own language, would be best equipped to judge the degree of credence to be attached to their reports of sightings.

In his account of the 1967 expedition's conclusions (5), Dr Dashdorj lists eleven localities, all on the northern slopes of Takhiin Shar nuruu, as having been the scene of reliably attested recent sightings: Khar serten uul, Elkhon gobi, Takhiin usni khundi, Takhiin us, Galvyn gozor uul, Khalzan burgediin uul, Khalzangiin us, Tsagan shalyn us, Nuuts us, Kharuul us, Toodogiin us. *

Professor Dashdorj's own conclusion (5) is as follows: 'Now, as before, I remain convinced that the Wild Horse still survives in the wilderness of the Gobi-Altai'. To this conclusion we may add that the Academy of Sciences in Ulan Bator has agreed in principle to the organisation of a joint British-Mongolian television expedition, at shared cost, to film the rarer and more spectacular Mongolian fauna - including Capra sibirica, Ovis ammon, Equus hemionus, Camelus bactrianus (wild form), Ursus arctos pruinosus, the Gobi bear (of which Dr Kaszab (3) reports a specimen recently taken in the Kagan Bogd uul mountains south of the Altai and now in Ulan-Bator museum) - and to search for and film E. przewalskii in the Takhiin Shar nuruu. So far, however, it has not proved possible to complete arrangements for the British side.

\section{REFERENCES}

(1) New sighting of Przewalski horses, Oryx, Dec. 1966, Vol. VIII, No. 6.

(2) J. Volf, Z.f.Säugetierkunde, (Parey, Hamburg) Bd.32, H.4, 1967, Pp. 245-6.

(3) Z. Kaszab, Z.f.Säugetierkunde, Bd.33, H.1, 1968, Pp. 62-3.

(4) I. Montagu, Communication, P.Z.S., Vol. 144, Pt.3, Pp. 425-429.

(5) (6) Letters dated 2.12.67 and 20.3.68.

(7) Letter dated 24.5.65.

(8) Letter from Professor Owen Lattimore dated 27.2.68.

*As indicated in the text 'Takh' is Mongolian for 'wild horse', 'Takhiin Shar' for 'yellow wild horse'. I am indebted to Professor Owen Lattimore, of Leeds University, for translation of several other of the local names: 'uul' is mountain; 'nuruu' spine; 'khundi' a damp hollow (i.e. dried river bed); 'us' water (i.e. a well, spring, pool or small oasis); 'gobi' (properly 'gov' in Mongolian) not a desert but a wilderness of thin vegetation that can be grazed; 'khalzang' bald or a horse with a white blaze; 'galvyn' an abomination of desolation, a disaster, or either of these ideas plus ice. It is noteworthy how often a word meaning water occurs in these place names. Dr Bannikov has expressed the view that the extinction of E. przewalskii is certain and that it will be the consequence not of deliberate slaughter but of the driving of this shy animal from its sources of water by the expansion of human population with its rival need of water even into such barren areas. Dr Kaszab, it will be recalled (1), thinks the construction and maintenance of a few artificial pools essential for its survival. 